\title{
Training to teach science: experimental evidence from Argentina
}

Facundo Albornoz; María Victoria Anauati; Melina Furman; Mariana Luzuriaga; María

Eugenia Podestá; Inés Taylor ${ }^{1}$

Abstract: We evaluate the learning impact of different teacher training methods using a random controlled trial implemented in 70 state schools in Buenos Aires, Argentina. A control group receiving standard teacher training was compared with two alternative treatment arms: providing a structured curriculum unit or receiving both the unit and weekly coaching. Following a 12-week intervention, there are substantial learning gains for students whose teachers were trained using structured curriculum units, as well as for those whose teachers received coaching (between $55 \%$ and $64 \%$ of a standard deviation more than those students in the control group). Coaching teachers does not appear to be a cost-effective, as the unit cost per 0.1 standard deviation is more than twice the cost of using only the structured curriculum unit. However, additional coaching is particularly beneficial for inexperienced teachers with less than 2 years of teaching Science. Coaching teachers also showed specific gains for girls, who both learned and declared to enjoy science lessons more. Higher-performing students especially benefited from both interventions, with students from coached teachers performing particularly well in harder questions. Using structured curriculum units and providing coaching also affected teacher perceptions: teachers expressed that they enjoyed teaching Science more, taught more hours of Science and that their students developed more skills. Results from a follow-up

\footnotetext{
${ }^{1}$ A supplementary online appendix is available with this article at the World Bank Economic Review website.
} 
survey suggest persistent change in teacher practice, with the vast majority reporting using the structured curriculum unit one year after the intervention.

\section{JEL Classification: C93, I21, I28.}

Keywords: Science education; Teacher training; Experimental study

Facundo Albornoz (corresponding author) is a Professor of Economics at the University of Nottingham and researcher at CONICET, Nottingham, UK; his email address is facundo.albornoz@nottingham.ac.uk. María Victoria Anauati is a doctoral student at CONICET, Argentina; her email address is victoria.anauati@gmail.com. Melina Furman is an Assistant Professor at Universidad de San Andrés and Researcher at CONICET, Argentina; her email address is mfurman@udesa.edu.ar. Mariana Luzuriaga is a Research Assistant at the Universidad de San Andrés, Argentina; her email address is mluzuriaga@udesa.edu.ar. María Eugenia Podestá is a Director of the Science Education Program at the Universidad de San Andrés, Argentina; her email is mepodesta@udesa.edu.ar. Inés Taylor is a Research Assistant at the Universidad de San Andrés, Argentina; her email address is itaylor@udesa.edu.ar. The research for this article was financed by CIAESA (Centro de Investigación Aplicada en Educación San Andrés). We are very grateful to Samuel Berlinski, Guillermo Cruces, Alejandro Ganimian, Lucila Minvielle and Abhijeet Singh for comments and suggestions. 


\section{INTRODUCTION}

Teacher training programs are ubiquitous across educational systems and constitute an essential tool to improve student learning and, thus, promote economic growth and development. Surprisingly, however, current approaches to teacher training are mainly uninformed by high quality evidence of their impact (Yoon, Duncan, Lee, Scarloss and Shapley, 2007). This is a serious issue especially because the different ways that programs can be designed and implemented involve a substantial variation in costs. In LatinAmerican countries, for example, total investments in teacher training represent a major element of non-salary public spending in education, but there are no rigorous evaluations of their impact on learning (Bruns and Luque, 2015), let alone an evaluation of the costeffectiveness of different designs when implementing them. Thus, how to design costeffective teacher training programs becomes one of the central questions of education policy. This paper provides experimental evidence on the impact and cost-effectiveness of different teacher professional development interventions on student Science learning from a specifically designed large-scale study, implemented in state primary schools in the Autonomous City of Buenos Aires, Argentina (hereafter CABA, for its Spanish acronym). While the experiment is specific to the instruction of Science in Argentina, the results may have broad relevance for other curriculum subjects and contexts.

A typical training program consists of a one-off, short training session (Darling-Hammond, Wei, Andree, Richardson, and Orphanos, 2009). This field experiment assesses the marginal gain of complementing this basic training with two distinct teacher training models that provide different on-going degrees of scaffolding. The first treatment is the provision of a structured curriculum unit (SC henceforth), a detailed teaching guide 
comprised of lesson-by-lesson plans which provide teachers with objectives, content knowledge and specific activities to implement with their students. The second treatment is supplementing the first two treatments (short training sessions plus SC unit) with weekly coaching. This allows us to study and compare a basic, one-off teacher training session with two distinct follow-up models, each with different degrees of support and associated costs.

More specifically, the main findings and associated policy lessons of a randomized controlled experiment designed to assess the effect of different working modalities with inservice teachers on student learning in Science are reported. As primary education is considered of key importance to lay the foundations of scientific literacy (Näslund-Hadley and Bando, 2016; Novak, 2005), this study focuses on 7th grade -the last level of primary school in CABA. The study involves 70 schools, which constitute a representative sample of CABA state primary schools. Although seeking to provide experimental evidence of teacher training in general, Science as a particular curriculum area has its own specific merit. Over the last decades, many governments and international organizations have advocated Science, Technology, Engineering and Maths (STEM) subjects and degrees to promote economic growth in a context of highly technological and rapidly changing societies and jobs. The promotion of scientific literacy has also been emphasized by standardized international student assessment programs such as the Program for International Student Assessment -PISA (OECD, 2016).

The interest in this specific educational setting is easy to explain. Argentina, like the rest of Latin-American countries, is a perfect setting to study the effect of different strategies teacher-training strategies for Science. Despite several government initiatives aimed at 
encouraging Science education (see e.g. Serra, 2001; Argentine Ministry of Education, 2007), the performance of Argentinian students in standardized assessments is still poor (UNESCO, 2016; Vegas, Ganimian and Bos, 2014). Even in CABA, the best performing Argentinian district, $41 \%$ percent of students only achieved the minimum level in Science, placing them as one of the lowest performing groups in the world (Martin et al., 2016; OECD, 2016).

For this study, the participating schools were randomly assigned to three groups. All teachers in the three groups received a short-term training session. Besides being widely used in other countries, this approach to teacher professional development is also the most common one in Argentina (Argentine National Institute of Teacher Training, 2016). Teachers that only received this short-term training form the Control Group. However, the literature indicates that gains in student achievement are weak and they can only be observed in longer training interventions with on-going support (Yoon, Duncan, Lee, Scarloss and Shapley, 2007) ${ }^{2}$. In a recent review, Arancibia, Popova, and Evans (2016) conclude that only a few characteristics of teacher training programs, such as the inclusion of supplemental materials, follow-up visits, and focus on a specific subject, are positively associated with student test score gains. Following this, as well as other indicators of best practice, both treatment arms include such characteristics.

The second group (Sequence Group henceforth), teachers received the same short-term training, but this was then complemented with on-going support through the use of a structured curriculum unit, which guided teachers in the organization, content and

\footnotetext{
${ }^{2}$ Some studies even show that a minimum of 50 or even 80 hours of training and continuous post-training support are required to observe any result (Gulamhussein, 2013).
} 
pedagogy of a given topic. Research shows that well-designed structured curriculum units can enhance training sessions by providing concrete ways of taking the approaches learnt in training directly to the classroom and serving as catalysts for local customization (Brown, 2009). Developing curriculum units is a key strategy followed by the Argentinian education authorities as part of their efforts to improve teaching (Argentine Ministry of Education, 2017; Educ.ar, 2005). However, the literature also highlights challenges associated with the use of structured curriculum units. In some cases teachers adapt these units, making the lessons easier and more aligned with their regular practice, which in turn lowers their cognitive load (Davis, Janssen and Van Driel, 2016). Additionally, many factors may influence how and why teachers choose to adapt curriculum units, such as their previous teaching experience, knowledge and beliefs about science and education, among others (Arias, Davis, Marino, Kademian, and Palincsar, 2016; Forbes and Davis, 2010).

One way to bridge the gap between structured curriculum units and the classroom and to help teachers truly understand the rationale behind each activity proposed in structured curriculum units is by providing teachers with pedagogical support (Kraft and Blazar, 2016). Thus, in the third group (Coaches Group henceforth), teachers received the same short-term training and structured curriculum unit as the Sequence Group, with the addition of individual tutoring from pedagogical coaches. Coaches worked with teachers on a weekly basis to promote the full understanding of the nature of the activities proposed in the curriculum unit, and provided extra support, explanations and feedback depending on each particular teachers' needs. The literature shows that coaches seem to increase the fidelity of implementation and improve teacher and student performance (Kretlow and Bartholomew, 2010). Kraft, Blazar and Hogan (2016) estimate that coaching raised student 
performance on standardized tests by 0.15 standard deviations and improved instructional practice by 0.58 standard deviations based on effect sizes reported in 44 studies that used experimental or quasi-experimental designs. This effect compares favorably when contrasted with the larger body of literature on teacher training (Yoon, Duncan, Lee, Scarloss and Shapley, 2007; Garet, Wayne, Stancavage, Taylor, Eaton, Walters, Song, Brown, Hurlburt, Zhu, Sepanik, and Doolittle, 2011).

Comparing these two treatment groups with the Control Group allows us to confidently establish the marginal effect of complementing training sessions with either just a structured curriculum unit or with additional coaching effort. The first set of results clearly suggests that there is a gain in terms of learning. Specifically, students in the Sequence Group and Coaches Group learned between $55 \%$ and $64 \%$ of a standard deviation more than those students in the Control Group, respectively. This is equivalent to an average increase in student achievement from the 50th to the 66th (70th) percentile, approximately, for a student moved from the control condition to the structured curriculum condition (coaches condition). The marginal costs of doing so are also relatively low compared to the benefits. Complementing training sessions with a structured curriculum unit costs (per student) 0.84 dollars per 0.1 standard deviations; in other words it costs 0.84 dollars to move a child from the 50th to the 53th percentile approximately, whereas complementing this intervention with additional coaching effort costs (per student) 2.28 dollars per 0.1 standard deviations.

Empirically establishing the additional effect of coaching with respect to a structured curriculum unit is also relevant in terms of policy. Although, in general terms, coaches 
seem to increase the impact of teacher professional development public policies, hiring, training and providing coaches is an expensive and human-resource intensive approach ${ }^{3}$. According to the results, there is no general additional benefit in terms of student learning when providing on-going coaching compared to the structured curriculum unit on its own. However, qualifying this result is another contribution of this paper. Also, additional coaching does make a difference for relatively inexperienced teachers. Specifically, students in the Coaches Group learned $82 \%$ of a standard deviation more than students in the Sequence Group when considering the least experienced teachers. Therefore, tutors add value for those teachers who are relatively inexperienced in teaching science, particularly when considering higher-order skills, which require more intensive teaching. This suggests that improving teaching in Science is not a matter of choosing the best strategy, but rather the one that best suits the specific teachers and learning goals in question.

Finally, a potential long-lasting effect of teacher training requires that the targeted teachers adopt the structured sequence and change their way of teaching. Thus, the obvious followup question is whether teachers under the treatment groups continued using the sequence a year after the training, when teaching the same topic. To answer this question, participant teachers were contacted in the Sequence and Coaches groups after the intervention to inquire about whether they continued using the sequence provided the prior year, even when this time their students were not going to be externally assessed. From this follow-up, almost every "treated" $7^{\text {th }}$ grade Science teacher that remained in the same school continued

\footnotetext{
${ }^{3}$ In Argentina, exact figures and numbers are not publicly available, but many in-service teacher professional development programs - in particular those which provide support for rural or non-central provinces - include and finance the training and deployment of coaches. For instance, a recent national initiative involved the hiring of coaches to support the work of 800.000 teachers (Argentine Ministry of Education, 2015).
} 
using the sequence (100\% in the Sequence and $89 \%$ in the Coaches Group, respectively). This is an encouraging finding as it suggests that the training produced persisting effects on teaching practices.

The effect of teaching training on the learning experience goes beyond scores. Their impact on other dimensions of the learning process is of independent interest, but this study shed further light on how the effective adoption of evidence-based Science teaching techniques affects the perceptions of students and teachers. The structured curriculum unit seems to be an effective instrument to enhance curiosity and interest among students. In particular, using an index that captures these aspects, pupils in the Sequence group present a scale $20 \%$ of a standard deviation higher than those in the Control Group. Results also show that both treatments favorably change teacher perceptions of their practices and their expectations of student learning. Compared to the Control Group, teachers in the Sequence and Coaches Groups present a scale between $63 \%$ and $100 \%$ higher in their perception that their teaching practices changed meaningfully, that they enjoyed teaching Science more, that they taught more hours of Science and that students learned more and developed more skills. Coaching teachers also showed specific gains for girls, who both learned and declared to enjoy science lessons more relative to those assigned to the Sequence group.

There is a growing body of the literature in economics devoted to evaluate the impact of different policy interventions at the school level. Most of this effort has gone into identifying the causal effects of two broad categories of interventions: (a) improving school 
inputs, such as textbooks or classroom libraries (Abeberese, Kumler, and Linden, 2014 $4^{4}$; Glewwe, Kremer, and Moulin, 2009; He, Linden and Margaret, 20095 ), remedial education and/or assistant teachers (Banerjee, Cole, Duo, and Linden, 2007; Jacob and Lefgren 2004a), computers and computer-aided instruction (Linden 2008, Barrera and Linden, 2009; Cristia, Ibarraran, Cueto, and Severin, 2012; Mo, Zhang, Luo, Qu, Huang, Wang, Qiao, Boswell, and Rozelle 2014; Muralidharan, Singh and Ganimian, 2016; Berlinski and Busso, 2017), and other instructional technology, like flashcards (He, Linden, and MacLeod, 2008) or flipcharts (Glewwe, Kremer, Moulin, and Zitzewitz, 2004); and (b) providing additional educational resources and their management, including the effect of voucher programs (Angrist, Bettinger, Bloom, King and Kremer, 2002) or lumps sum grants to schools (Das, Dercon, Habyarimana, Krishnan, Muralidharan, and Sundararaman, 2013), as well as organizational changes like, for example, curricular design (Harris, Penuel, DeBarger, D’Angelo and Gallagher, 2014; De Philippis, 2016), reducing class size (Angrist and Lavy, 1999; Urquiola, 2006; Krueger and Whitmore, 2002; Fredriksson, Ockert, and Oosterbeek, 2012), group tracking (Duflo, Dupas, and Kremer, 2011), enhancing teacher incentives (Duflo, Hanna, and Ryan, 2012; Glewwe, Ilias and Kremer, 2010), and providing large-scale assessments to inform improvements in school management and classroom instruction (de Hoyos, Ganimian, Holland, 2017). This study makes a contribution to both literatures insofar as training teachers has a direct effect on school inputs and is able to identify and evaluate alternative ways to organize and deliver

\footnotetext{
${ }^{4}$ The main component of the program evaluated by these authors was providing schools with a set of ageappropriate books. This component was completed with training teachers to incorporate Reading in the curriculum, and with a 31 day "read-a-thon" to encourage children to read and supporting teachers as they incorporate Reading into their classes.

${ }^{5} \mathrm{He}$, Linden and Margaret (2009) assessed a program that consisted of two main components: the child library and the activities carried out in class, which included using story books, flash cards for word and letter recognition, and charts to instruct children.
} 
this training.

The identification of the causal effect of on-the-job or in-service teacher training has received far less attention ${ }^{6}$. Most of this research in education economics uses regression discontinuity strategies to estimate the effect of different training programs. For example, Jacob and Lefgren (2004b) find no evidence on student achievement of an in-service training program targeting teachers of Math and Reading in elementary schools located in relatively poor areas, in the United States. Angrist and Lavy (2001) estimate the effect of in-service teacher training on achievement in Jerusalem elementary schools. In this case, results are more encouraging. They find that the training program improved test scores by 0.2 to 0.4 standard deviations in secular schools but they seemed to have no effect in religious schools (which were poorly organized).

More closely related to this study, there is an emerging literature on teaching training based on experimental evidence. Bassi, Meghir, and Reynoso (2016) use a randomized controlled trial to estimate the effectiveness of guided instruction methods in under-performing schools in Chile. Teachers in treated schools received detailed classroom guides and scripted material to follow in their lectures (similar to the Sequence intervention in this study). They find that only the most advantaged students within treated schools (students from higher income families within the lower income population) benefit from the

\footnotetext{
${ }^{6}$ There are a number of papers in the education literature studying the effect of on-the-job or in service teacher training programs. This literature has been recently reviewed by McEwen (2015), who concludes that most of these studies do not identify the pure effect of training as it usually overlaps with other type of treatments, such as class size reductions or other institutional treatments. Also these papers are based on small scale studies. An example of a RCT study on the effect of teacher training in Science is Sloan (1993), which involved a sample of 173 students and whose results on the positive effects of the intervention were later discarded by Yoon, Duncan, Lee, Scarloss and Shapley (2007) for not addressing clustering and multiple outcomes.
} 
program, improving test scores by almost 0.2 of a standard deviation. Finally, Cilliers and Taylor (2017) conduct a randomized evaluation of two interventions in South Africa aimed at improving early grade Reading. As in this study, both interventions involved a short training session but one of the groups received additional coaching sessions. They find that only the intervention complemented with coaching had an impact in reading proficiency (about 0.25 standard deviations relative to the Control Group).

The remainder of the paper is organized as follows: Section 2 presents the research context and Section 3 explains the design of the experiment, describes the components of the intervention and explains the data collection process. Section 4 presents the research sample. Section 5 presents descriptive statistics for the main variables. Section 6 discusses the identification strategy and Section 7 shows the main results of the paper. Finally, Section 8 concludes and reflects on the implications in educational policy.

\section{RESEARCH CONTEXT}

In Argentina, education from primary school through high school education is compulsory and free of charge. The country has one of the highest rates of literacy (98\%) and schoollife expectancy (16 years) in the world (World Bank, 2014). Although attendance and completion at the secondary school level remains an issue, primary education is considered to be universal.

According to official statistics, Argentina has 11 million students enrolled in four education

levels: pre-school (ages 3-5, 15.6\%); primary (ages 6-11, 41\%); secondary (ages 12-17, $35.5 \%$ ) and tertiary (ages 18-22, 7.9\%). The majority of these students (71\%) attend public 
schools (DINIECE, 2015) ${ }^{7}$.

Between 2003 and 2013 student numbers increased by approximately 10\%, while the number of teachers increased by more than $20 \%$ over roughly the same period (DINIECE, 2004; DINIECE, 2015). This allowed Argentina to reach a pupil-teacher ratio of 11, the lowest in Latin America after Cuba (OECD, 2016), although it is worth noting that this ratio varies considerably across provinces.

Although there have been large successes in terms of increasing coverage, the Argentinean education system fails to provide high quality education (at least as measured by standardized test scores). While other countries in the region improved learning outcomes since 2000 - measured by the OECD's Program for International Student Assessment (PISA) - Argentina's scores show no progress (at best) in Science, or even experienced a marginal decline between 2000 and 2012. ${ }^{8}$ According to the $2012^{9}$ study, Argentina ranked amongst the lowest of the participating countries (59 out of a possible 65) (OECD, 2014) ${ }^{10}$.

CABA, being the wealthiest jurisdiction in Argentina, exhibits some specific features; namely a lower share of students attending public schools (49\%) and higher levels of student achievement (DINIECE, 2015). Despite this, international assessments show that the level of achievement of CABA students in Science is still well below the OECD

\footnotetext{
${ }_{8}^{7}$ These figures do not include special and adult education.

${ }^{8}$ According to De Hoyos, Holland and Troiano (2015), there is a gradual increase in Argentina's Science scores between 2006 and 2012, but it is not statistically significant at conventional levels (95\%).

${ }^{9}$ Argentina participated in PISA 2015, but its results were excluded from the main report due to problems with sample design. However, CABA participated as an adjudicated region and was included in the results.

${ }^{10}$ In a similar vein, results of the UNESCO Second Regional Comparative and Explanatory Study (SERCE), applied to students of 3rd and 6th graders, show that only $11.4 \%$ of students of 6th grader were able to explain everyday situations based on scientific evidence, use models to explain natural phenomena or draw conclusions based on data (UNESCO, 2009).
} 
average (OECD, 2016). Problems with teaching and learning Science in CABA were also highlighted by the last wave of the Trends in International Mathematics and Science Study (TIMSS), according to which CABA students (4th- and 8th-graders) place at the bottom of the world ranking, just above Egypt and South Africa (Martin, Mullis, Foy and Hooper, 2016). These results are not surprising given the reality of science education in Argentina, where lessons are mostly teacher-centered and focused on the transmission of encyclopedic content, far from competency-based international learning standards, such as those assessed by TIMMS and PISA (Argentine Ministry of Education, 2007). Countries with high levels of scientific literacy tend to implement inquiry-based approaches which position students as active knowledge producers in a classroom community of practice, placing importance on the development of specific science skills and deep understandings (OECD, 2016).

\section{EXPERIMENTAL DESIGN}

A randomized controlled experiment was carried out to assess the effect of different teacher professional development approaches on student learning in Science. The intervention focused on a compulsory unit of the seventh grade Science national curriculum: the Human Body.

The intervention consisted of a random allocation of 70 CABA state primary schools to one of three experimental groups (the supplementary online Appendix S1, available with this article at the World Bank Economic Review website, describes the intervention's timeline). 
Thus, the unit of randomization was the school $^{11}$. All participating teachers involved received one in-service 4-hour training session, and were then asked to teach the Human Body Science unit according to national curriculum guidelines, over the following 12 weeks. During the training session, teachers discussed and took part in inquiry-based activities related to the teaching of the Human Body topic ${ }^{12}$. The session was designed and run by specialists in Science education at the School of Education, University of San Andrés (Argentina). Those teachers receiving only this training form the Control Group.

In the first treatment group (Sequence Group), teachers received the same 4-hour training session and a structured curriculum unit that outlined how to teach the Human Body using an inquiry-based approach. ${ }^{13}$ The structured curriculum unit focused not only on Human Body content, but also on the development of Science competencies, as defined by the ability to explain phenomena scientifically, evaluate and design scientific inquiry and interpret data and evidence scientifically (OECD, 2016). This document included experiential learning activities, which are a departure from more common and traditional teaching methods ${ }^{14}$, along with questions, approaches and worksheets for students. Science education specialists designed the structured curriculum unitin consultation with a group of seventh grade teachers who were not part of the schools selected for the study. Teachers were expected to adapt and implement these activities in their classrooms over the

\footnotetext{
${ }^{11}$ The randomization was at the school level and not at the classroom level because $46 \%$ of the schools in our sample shared the same science teacher for at least one of their classrooms. Therefore, assigning classrooms to different treatments was operationally impossible.

${ }^{12}$ Details on the specific activities carried out during this session are available upon request.

${ }^{13}$ Given that inquiry-based pedagogies have been shown to promote Science competencies (Minner, Levy and Century, 2009), this approach was chosen for this unit with a particular emphasis on active learning.

${ }^{14}$ Examples of these activities include investigating changes in heart rate, measuring lung capacity, dissecting organs and evaluating historical experiments. The structured curriculum unit designed for this study is available upon request.
} 
following 12 weeks.

In the second treatment group (Coaches Group), teachers also received the same 4-hour training session and structured curriculum unit, but their training was complemented with weekly sessions with a pedagogical coach. The coaches met with teachers at their schools during planning periods of 60 minute sessions over 12 weeks with the aim to guide and support teachers on how to implement the structured curriculum unit, as well as to enhance teacher reflection on their practice. The pedagogical coaches were recruited by the School of Education, University of San Andrés. They were selected based on their knowledge and prior experience in Science education, as well as their potential to create a positive working relationship with participating teachers. They all held at least a bachelor's degree in Science and/or pedagogical certification (Table S2.1 of Appendix S2 reports their main demographic characteristics). In addition, coaches received regular training sessions every fortnight throughout the intervention (a total of eight 3-hour meetings) and they were given access to an extensive library of guiding documents and resources to support their work.

\section{Design of the assessment instrument}

A central part of the design of any experiment is to determine the outcome measure, which in this case is student achievement in Science. Together with university specialists in Science education, an assessment instrument (hereafter referred to as the "Science test") was developed to measure learning and to potentially distinguish the gains from the different working modalities with teachers.

First, following an in-depth analysis of the unit of Human Body, the topics included in the Science test were determined. In addition to this, three levels of skills were outlined: (i) 
basic skills, which required students to recall scientific content (such as identifying organs) and read simple tables and graphs; (ii) medium-order skills, which required students to explain scientific phenomena and develop conclusions based on simple experimental data; and (iii) higher-order skills, which required students to describe how different body systems work together, identify researchable questions, design experiments to address hypothesis, explain scientific phenomena and draw conclusions based on more complex experimental data (Appendix S3 details the differences between these skills).

The Science test was developed using the following procedure: (1) a pool of items for basic, medium- and higher-order content areas were created following the structure of PISA and TIMMS Science questions; (2) experts reviewed the items; (3) the test was piloted in two 7th grade classrooms at schools not participating in the project, and performed thinkaloud exercises with students to better understand their answers and make adjustments; and (4) a panel of experts reviewed the final assessment instrument.

The outcome of this process was an 11-items Science test of approximately one hour of duration. It consisted of both multiple- choice and open-ended questions. This combination allowed evaluators to capture a wider range of student responses, including stronger evidence of critical thinking skills, than is typically associated with only multiple-choice tests (Stanger-Hall, 2012).The test was administered at the end of the intervention at each school by external observers to guarantee the fidelity of its implementation under strict exam conditions. The test had sound psychometric properties. The scale reliability coefficient (Cronbach's alpha) is 0.79 in the full sample data and 0.76 in the Control Group.The test also shows a statistically significant correlation of 0.37 across schools with 
the Language score in the local end-of-primary exam of 7th grade (FEPBA, for its Spanish acronym) 15 .

The Science test questions were weighted according to difficulty, with higher-order questions scoring 3 points, medium-order questions scoring 2 points and basic-skills questions scoring 1 point. Answers were classified as either "Correct", for which they achieved full marks; "Partially correct", for which they achieved half of the maximum marks for the given question; "Incorrect", for which no marks were given; and "Omitted", when no answer was given and for which no marks were given. Specialists corrected all tests using a common rubric, which was shared and discussed during a half-day training session.Answers that were challenging to classify were discussed and determined by multiple assessors.

\section{Experimental Data}

Data was collected on all students, teachers and schools. After the intervention, a student survey was conducted to collect socio-demographic data in order to check whether the randomly created groups of schools were comparable ${ }^{16}$.The Science test was administered after schools had completed their 12-week intervention, followed by a student questionnaire designed to measure fidelity of implementation, students' perceptions on the teaching they had experienced and their attitudes towards Science. These questions were later used to build an index that measured if learning was interesting and relevant as well as if teaching

\footnotetext{
${ }^{15}$ The FEPBA test was prepared and administered to $7^{\text {th }}$ grade students of both private and public schools in CABA by the Ministry of Education of CABA in 2014.

${ }^{16}$ The student survey was collected in the classroom and contained information on students' characteristics, their family and socioeconomic background.
} 
practices inspired curiosity (See Appendix S4 for a detailed description of the index). ${ }^{17}$ These questions were based on a validated instrument, the Tripod Survey for Students (Bill and Melinda Gates Foundation, 2012).

Before and after the intervention took place, teachers provided further additional information. As a baseline, a survey gathered background characteristics of teachers and general information about their Science class. In the post-intervention survey, teachers responded a set of questions to assess the fidelity of implementation of the intervention, as well as perceived changes in class dynamics and teaching practices.

Finally, administrative information was collected at the school level. This information included data on school and seventh grade enrollment, number of classrooms and teachers, repetition rate, promotion rate, over-aged rate, location of the schools and the Language score in the local end-of-primary exam of 7 th grade (FEPBA).

\section{THE SAMPLE}

The sample consisted of 70 state primary schools from 6 (out of 21) school districts within CABA, giving a representative sample of state primary schools in the jurisdiction ${ }^{18}$ These $^{2}$ 70 schools involved about 3,000 students, grouped into 136 seventh grade classes, and 99 Science teachers (Table 1). Participating schools were randomized into a Control Group of

${ }^{17}$ See, for example, the Measures of Effective Teaching (MET) project where results show that student surveys produce more consistent results than classroom observations or achievement gain measures (Bill and Melinda Gates Foundation, 2012).

${ }^{18}$ Currently, there are 455 state primary schools in CABA. Thus, the share of schools included in our sample is $15 \%$. 
24 schools and two treatment groups, each of them composed of 23 schools.

\section{[Please insert Table 1]}

On average, schools in the experiment were comparable to the rest of primary state schools throughout CABA. Further information was also gathered regarding the average characteristics of the 70 participating schools with the characteristics of the nonparticipating primary state schools in CABA (see Table S5.1 of Appendix S5). As shown, there are no significant statistical differences between participating and non-participating schools in their size, seventh grade size, and seventh grade classrooms, as well as in student's promotion rate, over-aged rate and drop-out rate per school ${ }^{19}$.There is only one statistically significant difference, at $90 \%$ of confidence, in student's repetition rate per school, which is slightly higher for the schools included in the experiment. However, there are no statistically different results in the FEPBA results. The distributions of study participants and non-study participants' scores also share a substantial common support (see Figure AS4.1 of Appendix S4). Finally, there are no statistically significant differences in the Social Vulnerability Index at the school district level, which ranks houses in each school district according to their degree of vulnerability in terms of material and nonmaterial assets ${ }^{20}$. Based on these results, we can confidently state that the participating

\footnotetext{
${ }^{19}$ Over-aged students are those who are older than the normal age for a grade level, as defined by law.

20 The Social Vulnerability Index (SVI) is a weighted index, calculated by the Ministry of Education of CABA, which assigns a value to each household according to its characteristics with respect to the material and non-material assets. In this way, households are ranked according to their degree of vulnerability.
} 
schools constitute a representative sample of the CABA primary state schools.

\section{RANDOMIZATION AND DESCRIPTIVE STATISTICS}

Pre-treatment main sample means and standard deviations for the full sample and experimental groups show that half of the students in the research sample are female and on average they are approximately 12 years old (see Table 2). The majority was born in Argentina (86\%). In relation to their socioeconomic background, approximately $70 \%$ of the students have parents with secondary education. In addition to this, $90 \%$ of the students have access to Internet in their homes; and 59\% and 64\% of them also owning at least one air conditioning and one car in their homes, respectively. Finally, about $65 \%$ of students missed, at most, one class per month since the beginning of this investigation (see Appendix S6 for more details on other variables).In terms of participating teachers, $88 \%$ of them are female with an average age of 42 years (also Table 2). Nearly $45 \%$ of teachers have a post-graduate certificate and, on average, they have about 12 years of teaching experience and 6.5 years of experience teaching Science. Almost all of the teachers had participated in some form of teacher training in the last two years and half of them hadnever used a structured curriculum unit.

Schools enroll an average of 301 students and 42 students in $7^{\text {th }}$ grade, which are, most commonly, divided in two classrooms (see Table 2). Repetition rate in $7^{\text {th }}$ grade is $3 \%$ on average, and school over-aged and promotion rate are on average $15 \%$ and $97 \%$, 
respectively.

The FEPBA score in Language, which presents an average of $448^{21}$, is also reported. We do not discuss the meaning of this score here, but use this variable with the sole intention of comparing student academic performance across our groups of CABA schools.

With regards to whether the experimental groups were similar with each other and representative, the differences in the means along with p-values from two-tailed t-tests of equality of means across experimental groups are shown (Table 3). As seen, the treatment and Control Groups do not differ significantly in any observable dimension. The only variable with a statistical difference at the $95 \%$ level of confidence is student age, where Control Group students are slightly younger than those in the Sequence. However, this difference is very small and vanishes when considering $7^{\text {th }}$ grade repetition rate, which is balanced across the three experimental groups (see Appendix S6 for further differences in the means of other variables).

[Please Insert Table 2]

[Please Insert Table 3]

${ }^{21}$ It is important to note that there is no school-specific measure of Science knowledge of $6^{\text {th }}$ or $7^{\text {th }}$ grade student available in Argentina or CABA. Therefore, to the best of our knowledge, FEPBA score in Language is the best approximation, based on administrative data, which we can make. 
Only $14.5 \%, 15.3 \%$ and $17 \%$ of students in the Control, Sequence and Coaches Group, respectively, did not complete the Human Body test. These are relatively low non-response rates and there is no statistically significant difference in the number of students who missed or omitted the test across the experimental groups (see Table 4). Finally, only 7 out of the 136 classrooms failed to teach the Human Body unit, which implies an attrition rate of 5\%. Excluding classrooms not completing the Human Body unit carries no effect on the balance across the experimental groups (see Table S7.1 in Appendix S7).

\section{[Please Insert Table 4]}

\section{IDENTIFICATION STRATEGY}

Our goal is to understand how using a structured curriculum or receiving, as a complement, weekly coaching meetings can influence learning outcomes in a randomized controlled experimental setting. In this setting, the Control Group estimates what would have happened to the treated groups in the absence of the intervention. The validity of the Control Group is evaluated by examining the exogeneity of treatment status with respect to the potential outcomes, and by testing whether pre-intervention characteristics of the treatment and Control Groups are reasonably similar. As discussed in Section 5, there is a strong similarity across the three experimental groups. The similarity across pre-treatment characteristics is consistent with the exogeneity in the allocation of schools in each treatment.

When the treatment status is exogenous, estimating the average treatment effects is 
straightforward. The random assignment of schools to treatment/Control Groups allows us to identify the average treatment effect by simply comparing the means of each of the two treatment groups with respect to the Control Group. Operationally, we estimate by Ordinary Least Squares a set of models of the following form:

$$
Y_{i j}=\alpha+\beta D T_{j}+\gamma X_{i j}+\theta_{j}+\varepsilon_{i j}
$$

where $i$ indexes students and $j$ indexes schools. $Y_{i j}$ is the outcome of interest (e.g., student performance in the Human Body test) of student $i$ in school $j . D T_{j}$ is a dummy variable indicating treatment status. We also include control variables $(X)$. Specifically, we control for students characteristics (gender, age, nationality, parent's education, if the student missed at most one class per month, if the student has internet in his home), teacher characteristics (gender, age, years of experience in teaching, if she/he has post-graduate certificates) and school characteristics (school size, $7^{\text {th }}$ size, $7^{\text {th }}$ repetition rate, FEPBA score in Language, school district -or location). The parameter of interest $\beta$ is the average treatment effect (e.g., the average effect on student performance in the Human Body test of being in the treatment group versus the status quo). Finally, $\varepsilon_{i j}$ is the error term.

The specifications of the model stated in equation (1) take into account the potential correlation between students' and teachers' performance and behavior by clustering the standard errors at the school level (i.e. the unit of randomization). However, the standard error estimates are typically not sensitive to the level of clustering.

For expositional reasons, we estimate equation (1) for each treatment separately. The results hold if we included both treatments in the same regression 22 .

22 The results of this estimation are available upon request. 
Section 7.1 contains the main results regarding the effect of the treatments on student learning. As their effects may depend on how teachers respond to the intervention, section 7.2 explores the average treatment effect conditioned to teacher experiences. Finally, section 7.3 extends our analysis beyond the test results and explores how the different interventions affected students' and teachers' perceptions about learning and teaching Science.

\section{Student Learning}

Table 5 shows the mean and standard deviation of the standardized score in the Science test, which was calculated using the mean and standard deviation of the Control Group, the score according to different levels of skills (Basic, Medium and Higher-order skills) as well as the percentage of correct, incorrect and omitted answers across experimental groups. This shows that the average score for the Sequence Group is 0.36 standard deviations higher than the average score for the Control Group, whereas the average score of the Coaches Group is 0.53 standard deviations higher that of the Control Group. This implies that both treatments were more effective in promoting middle- and higher-order skill development in students than basic skills. In addition to this, the percentage of correct answers increased in both treatments, while the percentage of incorrect and omitted answers decreased.

\section{[Please insert Table 5]}

With regards to student learning, the dependent variable is the standardized score in the

Science test, which was calculated using the mean and standard deviation of the Control 
Group (see Table 6). This allows interpreting the coefficient as the treatment effects in terms of the standard deviation. Columns (1) and (2) of panel A show the effect of the structured curriculum unit (Sequence Group) and the coaches (Coaches Group) in comparison with the Control Group. The estimated coefficients are all statistically significant and present a positive sign. The average treatment effect of the structured curriculum is an increase of 55\% of a standard deviation in Science scores and the average treatment effect of the coaches is an increase of $64 \%$ of a standard deviation in Science scores. Thus, students in the Sequence and Coaches Group learned between $55 \%$ and $64 \%$ of a standard deviation more than those students in the Control Group. This is equivalent to an average increase in student achievement from the 50th to the 66th percentile in the case of the Sequence Group whereas, if they were treated in the Coaches Group, the improvement goes from the 50th to the 70th percentile approximately. These effects are considered to be rather large for interventions with similar characteristics (see for example Allen et al (2011); Campbell and Malkus (2011); Sailors and Price (2010 and 2015); Matsumura, Garnier, Correnti, Junker, and DiPrima Bickel (2010); Bassi, Meghir, and Reynoso (2016)).

Although the estimated coefficient of the Coaches Group (column 2) is higher than that of the Sequence Group (column 1), its marginal effect is not statistically significant. This is shown in column 3 that presents the result of the Wald test, which evaluates the difference in the coefficient between column 1 and 2. This finding is relevant in terms of policy, as it would suggest that just the implementation of a structured curriculum is sufficient to improve short-term average results in learning outcomes in Science.

Panel B of Table 6 reports the same analysis but splitting the score according to different levels of skills (Basic, Medium and Higher-order skills). The findings are similar: although both treatments improve learning, there is no significant difference in their effects. 
Interestingly, the average treatment effect of the Coaches Group increases as the content evaluated (or items) becomes more complex (see column 2). This implies that, in these cases, the Coach treatment was more effective in promoting higher-order skill development in students than either the 4-hour training session or the provision of the structured curriculum unit.

The mechanism through which both the Sequence and Coaches treatments appear to increase Science test-scores involves an increase in the percentage of correct answers. Students in the Sequence and Coaches Group exhibit 10\% more correct answers than students in the Control Group (panel C). The treatments also reduce the number of omitted and incorrect answers. This suggests that the interventions did not only increase Science learning (which is shown in both the increase of correct answers and the reduction of incorrect ones), but also motivated students to answer more questions 23 .

\section{[Please insert Table 6]}

These findings are especially important given the large difference in treatments' costs. Whilst the cost per student for the Control Group was 1.4 dollars, for the Sequence Group the cost per student was 4.6 dollars and for the Coaches Group it was 14.7 dollars $^{24}$. This includes the costs of hiring and training the tutors, teacher seminar materials as well as curriculum unit design and printing. The estimates of Table 6 allow us to calculate the cost-effectiveness of

\footnotetext{
${ }^{23}$ The results of estimating equation (1) without controls are consistent with those reported in Table 6 and available upon request.

${ }^{24}$ Our calculations correspond to 2016 US dollar.
} 
the program. Providing teachers with a short-term training complemented with a structured curriculum costs (per student) 0.84 dollars per 0.1 standard deviations. Whereas, providing teachers with the same short-term training complemented with on-going coaching through the use of the same structured curriculum costs (per student) 2.28 dollars per 0.1 standard deviations. In other words, it costs 0.84 dollars to move a child from the 50th to the 53th percentile, approximately, in the first intervention, and 2.28 dollars in the second intervention. Therefore, providing teachers with a structured curriculum is 2.7 times more cost-effective for the total score than complementing it with on-going coaching. Even though cost effectiveness calculations might not be perfectly comparable across programs, in general terms, our calculations are in line with other interventions based on teacher training programs (see for example Banerjee, Cole, Duflo and Linden, 2007).

In order to deepen our analysis, we investigated whether any particular group of students experienced more gains in test-score results. Table S8.1 in Appendix S8 displays separate estimates for students below (first panel, "high performance") and above (second panel, "low performance") the mean test-score for each group. In general, both the use of the structured curriculum unit and the coaches seem to benefit higher performing students more than their lower performing peers: in both treatment groups, high performing students obtained a significantly higher percentage of correct answers and lower percentage of incorrect and omitted ones. In particular, the gain of high performing students in the Coaches Group is almost twice the gain of low performing students in the same group, while the gain of high performing students in the Sequence is $19 \%$ higher than the gain of low performing students in the same group. However, although the Coaches Group has a slightly higher impact in increasing test-scores than the Sequence for the high performing students, there is still no statistically significant difference between these two treatments (see column 3). 
Another factor of interest is to analyze whether learning results differ according student gender. Separate estimates of the average treatment effects for female and male students are reported in Table S8.2 in Appendix S8. As observed in column (1), there is no difference in the average treatment effect within the Sequence between girls and boys. However, column (2) shows that the average treatment effect of the coaches is higher for girls than boys. In particular, test-scores for girls in this group are almost 33\% higher than for boys, while the percentage of correct answers and omitted answers are near 25\% higher and 39\% lower for girls than boys respectively. Nevertheless, there is no difference in the average treatment effect of the coaches in comparison with the Sequence either for males or females (see column 3).

\section{The role of teachers' experience}

An important message conveyed from our results is that there is no statistical difference between supporting teachers with a structured curriculum unit and providing them the same unit with a pedagogical coach. This suggests that the additional learning gain from coaching in Science is weak. We explore in this section whether this result is conditional on teaching experience. To do so with estimate the following model using OLS:

$$
Y_{i j}=\alpha+\beta D T_{j}+\gamma X_{i j}+\mu\left(D T_{j} \times E_{i}\right)+v E_{i}+\theta_{j}+\varepsilon_{i j}
$$

where, as in equation (1), iindexes students and $j$ indexes schools. $Y_{i j}$ is the outcome of interest, i.e. student scores in the Human Body test. $D T_{j}$ is a dummy variable indicating treatment status. $X_{i j}$ represents a set of control variables (students characteristics: gender, age, nationality, parent's education, if the student missed at most one class per month, if he has internet in his home; teacher characteristics: gender, age, general teaching experience (in years), if she/he has post-graduate certificates; and school characteristics: school size, $7^{\text {th }}$ size, 
$7^{\text {th }}$ repetition rate, FEPBA score in Language, school district -or location). $D T_{j} \times E_{i}$ represents an interaction term between treatment status $(D T)$ and a dichotomous variable $(E)$ that equals to 1 if the teacher has less than two years of experience in teaching Science (first quartile in our sample) and zero otherwise, we call this variable "low experience". Now, our parameters of interest are $\beta$ (the average treatment effect) and $\mu$ (the marginal effect of teaching experience). Finally, $\varepsilon_{i j}$ is the error term.

From this, the average treatment effect of the Coaches Group versus the Sequence Group is conditioned by teacher experience in Science (see Table 7). Specifically, the average treatment effect of the coaches is an increase of $82 \%$ of a standard deviation in Science scores in comparison with the teaching sequence when considering the least experienced teachers (column 3). This increase in test-scores is considerable; and implies, therefore, that coaches add value for the teachers who were relatively inexperienced in teaching Science. The specific effect of each treatment is not conditional on the level of experience when compared to the Control Group. Also, comparing the coefficients associated with the Coaches Group in Tables 6 and 7, we observe that the effect of Coaches is lower when controlling for experience. The fact that the effect of Coaches is conditional on experience, whereas the effect of Sequence is not, is consistent with finding that the effect of providing teachers with Coaches is more relevant for low-experienced teachers.

[Please Insert Table 7] 
Furthermore, we explore if Science teaching experience affects the average treatment effect for the higher-order skills that we expect students to develop. This is particularly relevant as higher-order skills are those that underlie the development of both complex reasoning and scientific competencies, and therefore could be more challenging for teachers to enhance in students. The results of estimating equation (2) on the test-scores for higher-order skills confirm the finding that coaches add value in comparison with the teaching sequence for the least experienced teachers, and this is true when we considered the higher-order skills, which often require more intensive teaching (see Table 8).

\section{[Please insert Table 8]}

\section{Effects on Perceptions}

Looking beyond student test performances, whether treatments have any effects on student and teacher perceptions of Science lessons was also analyzed. As student motivation and perceptions are associated with learning outcomes (Christophel, 1990; Bill and Melinda Gates Foundation, 2012), this finding presents an important issue. The next subsections explore these issues from the perspectives of the students and teachers.

Student Perceptions. Students themselves are a primary source of information on the quality of teaching and the learning environment in individual classrooms (Bill and Melinda Gates Foundation, 2012). To explore whether our treatments affect student perceptions about learning Science, a "captivate" index was constructed to evaluate whether teaching practices inspired curiosity and interest, and whether teachers were able to hold the student's attention 
in class and provide the basis for continuing interest. The construction of this index is explained in Appendix S4.

Relating the captivate index (which ranges between -6 to 2$)^{25}$ to Science test scores, shows that classrooms in which students rated their teachers higher on the captivate index tended also to produce greater average achievement gains (see Figure 1). The black line, which shows the statistically significant partial correlation (0.08) of the scores and the captivate index controlling for students, teachers and schools' characteristics, confirms this relation.

[Please insert Figure 1]

The results of estimating equation (1) on the captivate index, as well as on each separate question (with a 4-point scale) that conforms it can be seen in Columns (1) and (2) (see Table 9), while column (3) shows the results of the Wald test, which evaluates the difference between the average treatment effect of the Sequence Group and the Coaches Group. The results suggest that the sequence treatment is an effective instrument for enhancing curiosity and interest among students.

\section{[Please insert Table 9]}

\footnotetext{
${ }^{25}$ The value of -6 indicates that the student strongly disagrees in all the questions included in the index (see Appendix S4). This means that, for that student, teacher practices do not inspire curiosity and interest at all, or fails to keep his attention in class. In contrast, the value of 2 indicates that the student strongly agrees in all the questions that make up the index suggesting that, for that student, teacher practices do inspire curiosity and interest or are successful in keeping his full attention in class.
} 
With regards to the gender perspective previously considered, we explore if girls experienced more gains in the captivate index than boys. Estimation of the equation (1) using the captivate index as the dependent variable for female and male students show that female students from the Sequence Group were more interested than their male classmates in comparison with the Control Group (see Table S9.1 in Appendix S9). Indeed, the captivate index for female students is $35 \%$ of a standard deviation higher than that of the Control Group. In contrast, the Coaches treatment seems to reduce the captivate index for females in comparison with the Sequence treatment, which does not happen when restricting the sample to male students.

Teacher Perceptions. Finally, this subsection explores the effect of the intervention on how teachers perceived their experience and the effects they observed in their students. For that, a 4-point-scale ${ }^{26}$ was constructed to measure the extent to which teachers agreed with the following statements: A. I feel that the way I teach Science changed a lot; B. I liked or enjoyed more teaching Science than previous years; C. I feel that by implementing the ideas of this training my students learned more in comparison with other groups and/or subjects; D. I feel my students developed more skills than in previous years; and E. I taught more hours of Science classes.

The results of estimating the effect of the treatments on these variables, controlling for teacher characteristics suggest that both the sequence and coaches treatments favorably changed teacher perceptions on their practices and their expectations of student learning (see Column (1) and (2) of Table 10). Compared to the Control Group, teachers in the Sequence Group (Coaches Group) present a scale 86\% (95\%) higher in their perception than their teaching practices meaningfully changed. In a similar vein, teachers in the Sequence Group

\footnotetext{
${ }^{26}$ In the 4-point-scale, 1 represents "strongly disagree", 2 "disagree", 3 "agree" and 4 "strongly agree".
} 
(Coaches Group) present a scale $72 \%$ (97\%) higher in their perception that they enjoyed more teaching Science in comparison with teachers of the Control Group. Furthermore, teachers in the Sequence Group (Coaches Group) present a scale between 63\% and 67\% (77\% and $88 \%$ ) higher in their perception that students learned more and developed more skills than teachers in the Control Group. Finally, according to column (3), which shows the results of a test that evaluates the difference between the coefficients in columns (1) and (2), teachers in the Coaches Group expressed that they taught more hours of Science than teachers in the Control and Sequence Groups. This is important as increasing class teaching hours is associated with improvements in learning outcomes (OECD, 2016). All of these differences are statistically significant.

\section{[Please insert Table 10]}

\section{Follow-up}

Lastly, this study explores the possibility of the longer-runimpact of the different training interventions evaluated. As shownabove, a structured sequenceusing an inquiry-based approach has a positive effect on how students learn a specific pedagogical content. Althoughlearning of a particular topicis likely to have a limited aggregate impact over time for a typical student,what is clearly required for a potential long-lasting effect of teachertrainingis that the targeted teachers adopt new teaching practices consistently over time. Thus, the obvious follow-up question is whether teachersunder our treatment groupscontinued using the sequencewhen teaching the same topic the following year. To answer this question, participant teachers in the Sequence and Couches Groups were 
contacted after the intervention to inquire about whether they continued using the sequence provided the prior year, even when this time their students were not going to be externally assessed.

In fact, almost every "treated" $7^{\text {th }}$ grade Science teacher that remained in the same school continued using the sequence (100\% in the Sequence Group and $89 \%$ in the Coaches Group)(see Table 11). This is an encouraging finding as it provides evidence suggesting a persistent change in teaching practices.

However, between $67 \%$ and $73 \%$ of the participant teachers were reassigned to either other grades or schools. That means that teaching turnover may dissipate part of the effect of the training. This is an issue that goes beyond the scope of our paper but increases its relevance when assessing the long-run impact of training initiatives.

[Please insert Table 11]

\section{CONCLUSION}

This study used a randomized controlled trial to assess the impact of different CPD approaches on student Science learning. 70 participating schools were randomly assigned to one of three conditions: (1) short-term teacher training (Control Group), (2) short-term teacher training complemented with a structured curriculum unit (Sequence Group), and (3) short-term teacher training complemented with both a structured curriculum unit and weekly tutoring from pedagogical coaches (Coaches Group). The study included 2965 students and 
99 teachers in the seventh grade of public schools in CABA, Argentina. The experiment was internally valid and performed on a representative sample of schools of CABA.

Providing teachers with a structured curriculum unit increased student performance by $55 \%$ of a standard deviation compared to a short-term training session. This finding is consistent with the literature that shows that developing high quality structured curriculum units are valid instruments for assisting teachers and promoting more effective teaching and learning (Brown, 2009). The structured curriculum unit also sparked interest and curiosity amongst students. Using an index that measures if learning was interesting and relevant as well as if teaching practices inspired curiosity, results show that students in the Sequence Group presented a scale $20 \%$ of a standard deviation higher than those in the Control Group. This finding supports research that shows that motivation is an essential factor to generate and sustain student learning (Ercan, Ural and Ates, 2016).

Also, students in the Coaches Group learned significantly more than those in the Control Group. Specifically, students whose teachers had a coach learned about $64 \%$ of a standard deviation more than those in the Control Group. However, there is no general additional benefit in terms of student learning between the structured curriculum unit by itself, and the unit with the addition of coaching. Nevertheless, the marginal effect of coaches is statistically significant for relatively inexperienced teachers in Science education. Specifically, students in the Coaches Group learned $82 \%$ of a standard deviation more than students in the Sequence Group when considering the least experienced teachers. This is particularly true when focusing on higher-order skills, which may require more targeted and specific teaching. This implies that coaches should be utilized for teachers who have little prior experience in teaching science and focus their support on getting teachers to master the teaching of cognitively demanding activities, rather than simply implement basic active learning 
strategies (which teachers seem to be able to pick up alone by just working with a structured curriculum unit).

Additionally, the average treatment effect of the coaches is higher for girls than boys. This is an encouraging finding as not only girls' participation and achievement in school science (Liben and Coyle, 2014) but also the choice of careers related to Science shows a noticeable gender gap (Beede, Julian, Langdon, McKittrick, Khan and Doms, 2011). This result may indicate that coaches help teachers create more gender inclusive Science lessons, supporting them in strategies that better cater to active participation of girls. In this sense, one important value of working with coaches would be promoting more female engagement in Science.

Both the structured curriculum unit and the pedagogical coaching improve teacher satisfaction with their practice and their perceptions of student learning. Compared to the Control Group, teachers in the Sequence Group and Coaches Group present a scale between $63 \%$ and $100 \%$ higher in their perception that their teaching practices meaningfully changed and that students learned more and developed more skills, that they enjoyed teaching Science more and that they taught more hours of Science. This last finding is particularly interesting, as a study analyzing the effective class time in given to science showed that CABA teachers do not tend to meet the required hours of Science (many times teaching less than half the jurisdictional requirement of hours as suggested by Furman et al., 2018). As more hours of teaching are associated with higher learning outcomes, and in particular improvements in higher-order skills (OECD, 2016), increasing science teaching hours is a valuable outcome. In this case, our findings support and further findings that show that teachers perceive tension between science and other curricular areas, but introducing coaches increases the time and confidence teachers feel with regards to teaching science (Berg \& Moore, 2014). 
The first policy recommendation that emerges from our study is that a short-term teacher training complemented with a structured curriculum should be considered a cost-effective CPD intervention to increase student learning in Science. Specifically, complementing training sessions with a structured curriculum unit costs (per student) 0.84 dollars per 0.1 standard deviations; implying that it costs 0.84 dollars to move a child from the 50 th to the 53th percentile approximately.

The second policy recommendation is that providing additional coaching does improve student scores, but only for relatively inexperienced teachers in Science. This finding suggests that experienced teachers already have the pedagogical toolkit that enables them to confidently implement the lessons outlined in the curriculum unit, at least up to a basic level. For less experienced teachers, coaching can bridge the gap between structured lesson plans and the complex world of the actual science classroom.

This suggests that improving teachers' practice in Science is not a matter of choosing the best ("one size fits all") CPD strategy, but selecting the strategy that best suits the specific population of teachers and student learning goals being targeted. These are relevant contributions for public policies focused on CPD interventions as hiring, training and providing coaches is an expensive and human-resource intensive approach. Our study shows that providing teachers with a structured curriculum unit is 2.7 times more cost-effective than complementing the unit with on-going coaching.

In all, our study speaks to the need to tailor CPD interventions in order to maximize their effects based on evidence of what works better and taking into account the cost-effectiveness of each strategy. We believe that evidence of this nature is urgent and necessary for the development of effective public policies aimed at promoting students scientific literacy and thus effective participation in the global knowledge economy. 


\section{References}

Abeberese, A. B., Kumler, T. J., and Linden, L. L. (2014). Improving Reading skills by encouraging children to read in school: A randomized evaluation of the Sa Aklat Sisikat Reading program in the Philippines. Journal of Human Resources, 49(3), 611633.

Allen, J. P., Pianta, R. C., Gregory, A., Mikami, A. Y., and Lun, J. (2011). An interactionbased approach to enhancing secondary school instruction and student achievement. Science, 333, 1034-1037.

Angrist, J. and Lavy, V. (2001). Does Teacher Training Effect Pupil Learning? Evidence from Matched Comparisons in Jerusalem Public Schools. Journal of Labor Economics, 19(2), 343-369.

Angrist, J., and Lavy, V. (1999). Using maimonides' rule to estimate the effect of class size on scholastic achievement. Quarterly Journal of Economics, 114 (2), 533_575.

Angrist, J., Bettinger, E., Bloom, E., King, E., and Kremer, M. (2002). Vouchers for private schooling in Colombia: Evidence from a randomized natural experiment. American Economic Review, 92, 1535-1558. doi:10.1257/000282802762024629

Arancibia, V., Popova, A., and Evans, D. K. (2016). Training Teachers on the Job: What Works and How to Measure it. Policy Research Working Paper, No. 7834. World Bank.

Argentine Ministry of Education (2007). Mejorar la enseñanza de las ciencias y las matemáticas - Una prioridad nacional. Buenos Aires: Argentine Ministry of 
Education. Retrieved from:

http://repositorio.educacion.gov.ar/dspace/handle/123456789/95085

Argentine Ministry of Education and Sports (2017). Aprender 2016. Primer informe de resultados. Buenos Aires: Argentine Ministry of Education and Sports.

Argentine Ministry of Education (2015). Presentación Nuestra Escuela - Programa Nacional de Formación Docente. Retrieved from:

http://nuestraescuela.educacion.gov.ar/pdf/presentacionnuestraescuela.pdf

Argentine National Institute of Teacher Training. (2016). Plan Nacional de Formación Docente 2016-2021. Buenos Aires: Argentine National Institute of Teacher Training. Retrieved from: http://cedoc.infd.edu.ar/upload/Plan_Nacional_de_Formacion_Docente1.pdf

Arias, A. M., Davis, E. A., Marino, J. C., Kademian, S. M., and Palincsar, A. S. (2016). Teachers' use of educative curriculum materials to engage students in science practices. International Journal of Science Education, 38(9), 1504-1526.

Banerjee, A., Cole, S., Duflo, E., and Linden, L. (2007). Remedying education: Evidence from two randomized experiments in India. Quarterly Journal of Economics, 122, 1235-1264. doi:10.1162/qjec.122.3.1235.

Barrera-Osorio, F., and Linden, L. L. (2009). The use and misuse of computers in education: Evidence from a randomized controlled trial of a language arts program. Unpublished manuscript, Columbia University, New York, NY.

Bassi, M., Meghir, C., and Reynoso, A. (2016). Education Quality and Teaching 
Practices. National Bureau of Economic Research, No. w22719.

Beede, D. N., Julian, T. A., Langdon, D., McKittrick, G., Khan, B., and Doms, M. E. (2011). Women in STEM: A gender gap to innovation. Economics and Statistics Administration, Issue Brief No. 04-11 Available at: https://papers.ssrn.com/sol3/papers.cfm?abstract_id=1964782

Berg, A., \& Moore Mensah, F. (2014). De-marginalizing science in the elementary classroom by coaching teachers to address perceived dilemmas. Education Policy Analysis Archives 22.

Berlinski, S., and Busso, M. (2017). Challenges in educational reform: An experiment on active learning in mathematics. Economics Letters, 156, 172-175.

Bill and Melinda Gates Foundation. (2012). Asking Students about Teaching. Student Perception Surveys and Their Implementation. Met Project. Policy and Practice Brief.

Brown, M. W. (2009). The teacher-tool relationship: Theorizing the Design and Use of Curriculum Materials. In Remillard, J. T., Herbel-Eisenmann, B. A., and Lloyd, G. M. (Eds.). (2011). Mathematics teachers at work: Connecting curriculum materials and classroom instruction. New York: Routledge.

Bruns, B., \& Luque, J. (2014). Profesores excelentes. Docentes excelentes: Cómo mejorar el aprendizaje en América Latina y el Caribe. Washington, DC: Banco Mundial. Retrieved from http://www. bancomundial. org/content/dam/Worldbank/Highlights\% 20\&\% 20Features/lac/LC5/Spanish-excellent-teachers-report. pdf. 
Buhl-Wiggers, J., Kerwin, J., Smith, J., and Thornton, R. (2017). The impact of teacher effectiveness on student learning in Africa. Working paper. Available at: https://editorialexpress.com/cgibin/conference/download.cgi?db_name=CSAE2017\&paper_id=1008Campbell, P. F., and Malkus, N. N. (2011). The impact of elementary mathematics coaches on student achievement. The Elementary School Journal, 111(3), 430-454.

Cilliers, J., \& Taylor, S. (2017). Monitoring Teachers and Changing Teaching Practice: Evidence from a Field Experiment. Working paper. Available at https://sites.tufts.edu/neudc2017/files/2017/10/paper_110.pdf

Christophel, D. M. (1990). The relationships among teacher immediacy behaviors, student motivation, and learning. Communication education, 39(4), 323-340.

Cristia, J. P., Ibarrarán, P., Cueto, S., Santiago, A., and Severín, E. (2012). Technology and child development: Evidence from the One Laptop per Child program (Working Paper No. IDB-WP-304). Washington, DC: Inter-American Development Bank.

Darling-Hammond, L., Wei, R. C., Andree, A., Richardson, N., and Orphanos, S. (2009). Professional learning in the learning profession. Washington, DC: National Staff Development Council. Retrieved from http://www.ostrc.org/docs/document_library/ppd/Professionalism/Professional\%20Le arning\%20in\%20the\%20Learning\%20Profession.pdf

Das, J., S. Dercon, J. Habyarimana, P. Krishnan, K. Muralidharan, and V. Sundararaman (2013).When can school inputs improve test scores? American Economic Journal: Applied Economics, 5(2), 29-57. 
Davis, E. A., Janssen, F. J., and Van Driel, J. H. (2016). Teachers and science curriculum materials: where we are and where we need to go. Studies in Science Education, 52(2), 127-160.

De Hoyos Navarro, R., Ganimian, A. J., and Holland, P. (2017). Teaching with the test: experimental evidence on diagnostic feedback and capacity building for public schools in Argentina. Policy Research Working Paper, No. 8261. Washington, DC: The World Bank

De Hoyos, R., Holland, P. A., and Troiano, S. (2015). Understanding the trends in learning outcomes in Argentina, 2000 to 2012. Policy Research Working Paper, No. 7518. Washington, DC: The World Bank

De Philippis, M. (2016). STEM graduates and secondary school curriculum: does early exposure to science matter?. CEP Discussion Paper No 1443, Center for Economic Performance, The Landon School of Economics and Political Science.

DINIECE. (2004). Programme for International Student Assessment. Informe Nacional República Argentina. Buenos Aires: DiNIECE. Retrieved from http://repositorio.educacion.gov.ar/dspace/handle/123456789/55289

DINIECE. (2015). Anuario Estadístico Educativo. Relevamientos anuales 2007-2014.Buenos Aires: DiNIECE. Retrieved from http://portales.educacion.gov.ar/diniece/

Duflo, E, Hanna, R., and Ryan, S. (2012). Incentives work: Getting teachers to come to school. American Economic Review, 102(4), 1241-1278. 
Duflo, E., Dupas, P., and Kremer, M. (2011). Peer effects, teacher incentives, and the impact of tracking: Evidence from a randomized evaluation in kenya. American Economic Review, 101(5), 1739-1774.

Educ.ar. (2005). Anuario-En cifras. Retrieved from http://portal.educ.ar/acercade/anuarios/2006/cifras.html

Ercan, O., Ural, E., and Ateş, D. (2016). The Effect of Educational Software Based on Ausubel's Expository Learning on Students' Academic Achievement, Science and Computer Attitudes: "Human and Environment" Unit Example. British Journal of Education, Society \& Behavioural Science, 14(1): 1-10.

Forbes, C. T., and Davis, E. A. (2010). Curriculum design for inquiry: Preservice elementary teachers' mobilization and adaptation of science curriculum materials. Journal of research in science teaching, 47(7), 820-839.

Fredriksson, P., Ockert, B., and Oosterbeek, H. (2012). Long term effects of class size. Quarterly Journal of Economics, 249-285.

Furman, M., Luzuriaga, M., Taylor, I., Anauati, M. V., and Podestá, M. (in press) “Abriendo la "caja negra"del aula de ciencias: un estudio sobre la relación entre las prácticas deenseñanza y las capacidades de pensamiento que se promueven en losalumnos" [Opening the "black box" of the science classroom: a study on the relationship between teaching practices and thinking skills that are promoted in students]. Enseñanza de las Ciencias.

Garet, M. S., Wayne, A. J., Stancavage, F., Taylor, J., Eaton, M., Walters, K., Song, M., Brown, S., Hurlburt, S., Zhu, P., Sepanik, S. and Doolittle, F. (2011). Middle School 
Mathematics Professional Development Impact Study: Findings after the Second Year of Implementation. NCEE 2011-4024. National Center for Education Evaluation and Regional Assistance.

Glewwe, P., Kremer, M. and Moulin, S. (2009). Many Children Left Behind? Textbooks and Test Scores in Kenya. American Economic Journal: Applied Economics, 1(1), 11235.

Glewwe, P., Kremer, M., Moulin, S., and Zitzewitz, E. (2004). Retrospective vs. prospective analyses of school inputs: the case of flip charts in Kenya. Journal of development Economics, 74(1), 251-268.

Glewwe, P., N. Ilian, and M. Kremer (2010). Teacher incentives. American Economic Journal: Applied Economics, 2(3), 205-227.

Gulamhussein, A. (2013). Teaching the teachers: Effective professional development in an era of high stakes accountability. Center for Public Education, 1-47. Retrieved from goo.gl/DYNuct

Harris, C. J., Penuel, W. R., DeBarger, A., D’Angelo, C., and Gallagher, L. P. (2014) Curriculum materials make a difference for Next Generation Science Learning: Results from year 1 of a randomized controlled trial. Menlo Park, CA: SRI International. Retrieved from https://www.sri.com/sites/default/files/publications/pbis-efficacy-study-y1-outcomesreport-2014_0.pdf

He, F., L. Linden, and M. Margaret (2009). A better way to teach children to read? evidence from a randomized control trial. Unpublished manuscript, Columbia University. 
He, F., Linden, L. L., and MacLeod, M. (2008). How to teach English in India: Testing the relative productivity of instruction methods with Pratham English Language Education Program. Unpublished manuscript, Columbia University, New York, NY.

Jacob, B. A., and Lefgren, L. (2004a). Remedial education and student achievement: A regressiondiscontinuity approach. Review of Economics and Statistics, 86(1), 226244.

Jacob, B. and Lefgren, L. (2004b) The Impact of Teacher Training on Student Achievement: Quasi-Experimental Evidence from School Reform Efforts in Chicago. Journal of Human Resources, 39(1), 50-79.

Kraft, M. A., and Blazar, D. (2016). Individualized coaching to improve teacher practice across grades and subjects: New experimental evidence. Educational Policy (advance online publication). Retrieved from http://journals.sagepub.com/doi/abs/10.1177/0895904816631099

Kraft, M. A., Blazar, D., and Hogan, D. (2016). The Effect of Teacher Coaching on Instruction and Achievement: A Meta-Analysis of the Causal Evidence. Brown University Working Paper.

Kretlow, A. G., and Bartholomew, C. C. (2010). Using coaching to improve the fidelity of evidence-based practices: A review of studies. Teacher Education and Special Education: The Journal of the Teacher Education Division of the Council for Exceptional Children, 33(4). 279 - 299. 
Krueger, A. and Whitmore, D. (2002). "Would Smaller Classes Help Close the Black-White Achievement Gap?" In John E. Chubb and Tom Loveless, (eds.), Bridging the Achievement Gap. Washington: Brookings Institution Press.

Liben, L. S., and Coyle, E. F. (2014). Chapter three-developmental interventions to address the STEM gender gap: exploring intended and unintended consequences. Advances in child development and behavior, 47, 77-115.

Linden, L. L. (2008). Complement or substitute? The effect of technology on student achievement in India. Unpublished manuscript, Columbia University, New York, NY.

Martin, M. O., Mullis, I. V. S., Foy, P., and Hooper, M. (2016). TIMSS 2015 International Results in Science. Boston College: TIMSS \& PIRLS International Study Center. Retrieved from http://timssandpirls.bc.edu/timss2015/international-results/

Matsumura, L. C., Garnier, H. E., Correnti, R., Junker, B., and DiPrima Bickel, D. (2010). Investigating the effectiveness of a comprehensive literacy coaching program in schools with high teacher mobility. The Elementary School Journal, 111(1), 35-62.

McEwan, P. J. (2015). Improving learning in primary schools of developing countries: A meta-analysis of randomized experiments. Review of Educational Research, 85(3), 353-394.

Minner, D. D., Levy, A. J., and Century, J. (2010). Inquiry-based science instruction—what is it and does it matter? Results from a research synthesis years 1984 to 2002. Journal of research in science teaching, 47(4), 474-496. 
Mo, D., Zhang, L., Luo, R., Qu, Q., Huang, W., Wang, J., Qiao, Y., Boswell, M., and Rozelle, S. (2014). Integrating computer-assisted learning into a regular curriculum: evidence from a randomised experiment in rural schools in Shaanxi. Journal of development effectiveness, 6(3), 300-323.

Muralidharan, K., Singh, A., and Ganimian, A. J. (2016). Disrupting Education? Experimental Evidence on Technology-Aided Instruction in India. National Bureau of Economic Research, No. w22923.

Näslund-Hadley, E., and Bando, R. (Eds.) (2016). Todos los niños cuentan: enseñanza temprana de las matemáticas y ciencias en América Latina y el Caribe. Washington, DC: Banco Interamericano de Desarrollo. Retrieved from http://doi.org/http://dx.doi.org/10.18235/0000226\#sthash.7MqRqw2c.dpuf

Novak, J. D. (2005). Results and implications of a 12-year longitudinal study of science concept learning. Research in Science Education, 35(1), 23-40

OECD (2014), PISA 2012 Results: What Students Know and Can Do (Volume I, Revised edition) Student Performance in Mathematics, Reading and Science. Paris: OECD Publishing.

OECD (2016). PISA 2015 Results (Volume 1): Excellence and Equity in Education.Paris: OECD Publishing.

Organización de las Naciones Unidas para la Educación la Ciencia y la Cultura (UNESCO) (2009). Aportes para la enseñanza de las Ciencias Naturales: Segundo estudio Regional Comparativo y Explicativo (SERCE). Santiago de Chile: OREALC/UNESCO. 
Organización de las Naciones Unidas para la Educación la Ciencia y la Cultura (UNESO). (2016). Informe de resultados TERCE. Logros De Aprendizaje. Santiago de Chile: OREALC/UNESCO. Retrieved from http://unesdoc.unesco.org/images/0024/002435/243532S.pdfUNESCO 2015

Sailors, M., and Price, L. (2010). Professional Development that supports the teaching of cognitive Reading strategy instruction. Elementary School Journal, 110, 301e323.

Sailors, M., and Price, L. (2015). Support for the Improvement of Practices through Intensive Coaching (SIPIC): A model of coaching for improving Reading instruction and Reading achievement. Teaching and Teacher Education, 45, 115-127.

Serra, J. C. (2001) "La política de capacitación docente en Argentina: La Red Federal de Formación Docente Continua (1994-1999)." Ministry of Education, Argentina

Sloan, H. A. (1993). Direct instruction in fourth and fifth grade classrooms. Dissertation Abstracts International, 54(08), 2837A.

Stanger-Hall, K. F. (2012). Multiple-choice exams: an obstacle for higher-level thinking in introductory science classes. CBE-Life Sciences Education, 11(3), 294-306.

Urquiola, M. (2006). Identifying class size effects in developing countries: Evidence from rural bolivia. Review of Economics and Statistics, 88 (1), 171-177.

Valverde, G. and Näslund-Hadley, E. (2010). La condición de la educación en matemáticas y ciencias naturales en América Latina y el Caribe. Technical Notes, IDB-TN-211. Washington, DC: InterAmerican Developmnet Bank (IADB). 
Vegas, E., Ganimian, A. and Bos, M. S. (2014). América Latina en PISA 2012: ¿Cuántos estudiantes tienen bajo desempeño?Washington, DC: InterAmerican Developmnet Bank (IADB). Retrieved from https://publications.iadb.org/handle/11319/701

World Bank. (2014). Argentina-Country partnership strategy for the period of FY2015-18. Washington, DC: World Bank Group. Retrieved from http://documents.worldbank.org/curated/en/846861468210572315/ArgentinaCountry-partnership-strategy-for-the-period-of-FY2015-18

Yoon, K. S., Duncan, T., Lee, S. W. Y., Scarloss, B., and Shapley, K. L. (2007). Reviewing the Evidence on How Teacher Professional Development Affects Student Achievement. (Issues \& Answers Report, REL 2007-No. 033). Washington, DC: U.S. Department of Education, Institute of Education Sciences, National Center for Education Evaluation an Regional Assistance, Regional Educational Laboratory Southwest. 


\section{Figure titles and captions}

\section{Figure 1. Science scores and Captivate Index}

\section{Caption:}

Note: Controls include: (i) students characteristics (gender, age, nationality, parent's education, if the student missed, at most, one class per month, if the student has internet in his home), (ii) teacher characteristics (gender, age, years of experience, if she/he has postgraduate certificates), and (iii) school characteristics (school size, $7^{\text {th }}$ size, $7^{\text {th }}$ repetition rate, FEPBA score in Language, school district -or location). Both the captivate index and the Science cores are standardized in terms of the Control Group. The captivate index is combined scale, whose construction is described in Appendix S4. 


\section{$\underline{\text { Tables }}$}

Table 1. Background characteristics of the sample

\begin{tabular}{lcccc}
\hline & All & Control & Sequence & Coaches \\
& sample & Group & Group & Group \\
\hline Number of schools & 70 & 24 & 23 & 23 \\
Average students per school & 301 & 316 & 289 & 297 \\
Number of class divisions in 7th grade & 136 & 50 & 44 & 42 \\
Number of students in 7th grade & 2965 & 1086 & 917 & 962 \\
Number of Science teachers in 7th grade & 99 & 36 & 32 & 31 \\
\end{tabular}

Source: Authors analysis based on data described in text. 
Table 2. Pre-treatment characteristics

\begin{tabular}{|c|c|c|c|c|c|c|c|c|c|}
\hline & \multicolumn{3}{|c|}{ All simple } & \multirow{2}{*}{$\begin{array}{l}\text { Control Group } \\
\text { Mean }\end{array}$} & \multicolumn{3}{|c|}{ Sequence Group } & \multicolumn{2}{|c|}{ Coaches Group } \\
\hline & $\mathrm{N}$ & Mean & $\mathrm{Sd}$ & & $\mathrm{Sd}$ & Mean & $\mathrm{Sd}$ & Mean & $\mathrm{Sd}$ \\
\hline \multicolumn{10}{|l|}{ Student-level variables } \\
\hline Percent female & 2359 & 0.49 & 0.50 & 0.51 & 0.50 & 0.48 & 0.50 & 0.49 & 0.50 \\
\hline Age & 2346 & 12.19 & 0.52 & 12.17 & 0.49 & 12.22 & 0.55 & 12.18 & 0.52 \\
\hline Percent of Argentines & 2341 & 0.86 & 0.34 & 0.86 & 0.35 & 0.87 & 0.34 & 0.86 & 0.35 \\
\hline Mother or father education (secondary) & 1858 & 0.71 & 0.46 & 0.72 & 0.45 & 0.71 & 0.45 & 0.69 & 0.46 \\
\hline Have internet in their home & 2279 & 0.90 & 0.31 & 0.91 & 0.29 & 0.89 & 0.32 & 0.89 & 0.31 \\
\hline Have air conditioning in their home & 2130 & 0.59 & 0.49 & 0.60 & 0.49 & 0.60 & 0.49 & 0.58 & 0.49 \\
\hline Have at least one car in their home & 2162 & 0.64 & 0.48 & 0.64 & 0.48 & 0.66 & 0.48 & 0.62 & 0.49 \\
\hline At most, missed one class per month & 2288 & 0.65 & 0.48 & 0.66 & 0.48 & 0.64 & 0.48 & 0.64 & 0.48 \\
\hline \multicolumn{10}{|l|}{ Teacher-level variables } \\
\hline Percent female & 91 & 0.88 & 0.33 & 0.85 & 0.36 & 0.89 & 0.32 & 0.90 & 0.31 \\
\hline Age & 90 & 41.52 & 8.75 & 39.59 & 8.69 & 42.64 & 9.46 & 42.75 & 7.94 \\
\hline Percent with Post-Graduate Certificate & 91 & 0.43 & 0.50 & 10.42 & 6.67 & 12.68 & 6.49 & 12.26 & 8.36 \\
\hline Percent with University degree & 91 & 0.10 & 0.30 & 5.81 & 5.58 & 7.04 & 5.62 & 6.75 & 7.79 \\
\hline Seniority in teaching (in years) & 91 & 11.70 & 7.19 & 3.52 & 3.28 & 4.09 & 3.49 & 3.23 & 4.29 \\
\hline Seniority in teaching Science (in years) & 88 & 6.48 & 6.33 & 0.35 & 0.49 & 0.50 & 0.51 & 0.45 & 0.51 \\
\hline Percent of teachers that participated in trainings & 91 & 0.90 & 0.30 & 0.91 & 0.29 & 0.96 & 0.19 & 0.83 & 0.38 \\
\hline Percent of teachers that used a teaching sequence & 91 & 0.55 & 0.50 & 0.62 & 0.49 & 0.46 & 0.51 & 0.55 & 0.51 \\
\hline \multicolumn{10}{|l|}{ School-level variables } \\
\hline Students per school & 70 & 301.20 & 132.10 & 316.50 & 139.60 & 289.60 & 127.70 & 296.80 & 132.80 \\
\hline Students of 7 th grade & 70 & 42.36 & 19.42 & 45.25 & 22.16 & 39.87 & 16.85 & 41.83 & 19.21 \\
\hline School promotion rate $(\%)$ & 70 & 0.97 & 0.02 & 0.98 & 0.03 & 0.97 & 0.02 & 0.97 & 0.02 \\
\hline School drop-out rate $(\%)$ & 70 & 0.00 & 0.01 & 0.00 & 0.00 & 0.00 & 0.01 & 0.00 & 0.00 \\
\hline School over-aged rate $(\%)$ & 70 & 0.15 & 0.07 & 0.15 & 0.08 & 0.16 & 0.08 & 0.14 & 0.06 \\
\hline FEPBA score in Language & 70 & 488.16 & 18.05 & 487.03 & 18.17 & 487.86 & 20.02 & 489.66 & 16.49 \\
\hline
\end{tabular}

Note: $\mathrm{N}$ means number of observation in the full sample and $\mathrm{Sd}$ means standard deviation.

Source: Authors analysis based on data described in text. 
Table 3: Balance across Treatments

\begin{tabular}{|c|c|c|c|}
\hline & $\begin{array}{l}\text { Sequence vs. } \\
\text { Control }\end{array}$ & $\begin{array}{l}\text { Coaches vs. } \\
\text { Control }\end{array}$ & $\begin{array}{l}\text { Coaches vs. } \\
\text { Sequence }\end{array}$ \\
\hline \multicolumn{4}{|l|}{ Student-level variables } \\
\hline Percent female & -0.03 & -0.02 & 0.01 \\
\hline Age & $0.06 * *$ & 0.01 & -0.04 \\
\hline Percent of Argentines & 0.01 & 0.00 & -0.01 \\
\hline $\begin{array}{l}\text { Mother or father education } \\
\text { (secondary) }\end{array}$ & -0.01 & -0.04 & -0.03 \\
\hline Have internet in their home & -0.03 & -0.02 & 0.00 \\
\hline Have air conditioning in their home & 0.00 & -0.02 & -0.02 \\
\hline Have at least one car in their home & 0.02 & -0.02 & -0.04 \\
\hline $\begin{array}{l}\text { At most, missed one class per } \\
\text { month }\end{array}$ & -0.02 & -0.02 & -0.01 \\
\hline \multicolumn{4}{|l|}{ Teacher-level variables } \\
\hline Percent female & 0.04 & 0.04 & 0.00 \\
\hline Age & 3.06 & 3.16 & 0.11 \\
\hline Percent with Post-Graduate & 0.15 & 0.10 & -0.05 \\
\hline \multicolumn{4}{|l|}{ Certificate } \\
\hline Percent with University degree & 0.13 & 0.11 & 0.10 \\
\hline Seniority in teaching (in years) & 2.26 & 1.84 & -0.42 \\
\hline $\begin{array}{l}\text { Seniority in teaching Science (in } \\
\text { years) }\end{array}$ & 1.23 & 0.94 & -0.29 \\
\hline $\begin{array}{l}\text { Percent of teachers that participated } \\
\text { in trainings }\end{array}$ & 0.05 & 0.08 & $-0.14 *$ \\
\hline $\begin{array}{l}\text { Percent of teachers that used a } \\
\text { teaching sequence }\end{array}$ & 0.15 & 0.07 & 0.09 \\
\hline \multicolumn{4}{|l|}{ School-level variables } \\
\hline Students per school & -26.98 & -19.72 & 7.26 \\
\hline Students of 7 th grade & -5.38 & -3.42 & 1.96 \\
\hline School promotion rate $(\%)$ & -0.01 & 0.00 & 0.01 \\
\hline School drop-out rate $(\%)$ & 0.00 & 0.00 & 0.00 \\
\hline School over-aged rate $(\%)$ & 0.01 & 0.00 & -0.01 \\
\hline 7th student's repetition rate $(\%)$ & 0.02 & 0.00 & -0.02 \\
\hline FEPBA score in Language & 0.83 & 2.63 & 1.80 \\
\hline
\end{tabular}

Note: Each entry indicates the mean difference between the two experimental groups in the column for the corresponding variable in each line. * indicates that the difference of means test is significant at $10 \%$;** significant at $5 \%$; *** significant at $1 \%$.

Source: Authors analysis based on data described in text. 
Table 4. Differences in non-Response Rates

\begin{tabular}{|c|c|c|c|}
\hline & $\begin{array}{l}\text { Sequence } \\
\text { vs. } \\
\text { Control } \\
\text { (1) }\end{array}$ & $\begin{array}{l}\text { Coaches } \\
\text { vs. } \\
\text { Control } \\
(2)\end{array}$ & $\begin{array}{c}\text { Coaches } \\
\text { vs } \\
\text { Sequence } \\
(3)\end{array}$ \\
\hline Missing (or omitting) student test & 0.008 & 0.025 & 0.017 \\
\hline
\end{tabular}


Table 5. Mean and Standard deviation of learning outcomes

\begin{tabular}{lcccccccccc}
\hline \multirow{2}{*}{ Variable } & \multicolumn{3}{c}{ Control Group } & \multicolumn{3}{c}{ Sequence Group } & \multicolumn{3}{c}{ Coaches Group } \\
\cline { 2 - 11 } & $\mathrm{N}$ & Mean & $\mathrm{Sd}$ & $\mathrm{N}$ & Mean & $\mathrm{Sd}$ & $\mathrm{N}$ & Mean & $\mathrm{Sd}$ \\
\hline Science score & 790 & 0 & 1 & 771 & 0.506 & 1.119 & 801 & 0.681 & 1.156 \\
Science score (Basic skills) & 790 & 0 & 1 & 771 & 0.185 & 0.998 & 801 & 0.292 & 0.966 \\
Science score (Medium skills) & 790 & 0 & 1 & 771 & 0.554 & 1.088 & 801 & 0.583 & 1.102 \\
Science score (Higher-order & 790 & 0 & 1 & 771 & 0.386 & 1.134 & 801 & 0.654 & 1.195 \\
skills) & & & & & & & & & \\
Percent of correct answers & 790 & 0.326 & 0.202 & 771 & 0.409 & 0.24 & 801 & 0.436 & 0.243 \\
Percent of incorrect answers & 790 & 0.217 & 0.16 & 771 & 0.166 & 0.158 & 801 & 0.161 & 0.153 \\
Percent of omitted answers & 790 & 0.203 & 0.203 & 771 & 0.145 & 0.171 & 801 & 0.113 & 0.166 \\
\hline
\end{tabular}

Note: $\mathrm{N}$ means number of observation and Sd means standard deviation.

Source: Authors analysis based on data described in text. 
Table 6. Results on Science learning

\begin{tabular}{|c|c|c|c|}
\hline Dependent variable & $\begin{array}{c}\text { Sequence } \\
\text { vs. Control } \\
\text { (1) }\end{array}$ & $\begin{array}{c}\text { Coaches vs. } \\
\text { Control } \\
(2)\end{array}$ & $\begin{array}{c}\text { Wald Test } \\
\text { (3) }\end{array}$ \\
\hline \multicolumn{4}{|c|}{ Panel A } \\
\hline Science score & $\begin{array}{c}0.550^{* * *} \\
(0.125)\end{array}$ & $\begin{array}{c}0.647 * * * \\
(0.137)\end{array}$ & $\begin{array}{c}0.45 \\
{[0.502)}\end{array}$ \\
\hline Observations & 1,105 & 1,110 & \\
\hline \multicolumn{4}{|c|}{ Panel B } \\
\hline Science score (Basic skills) & $\begin{array}{c}0.276^{* * * *} \\
(0.081)\end{array}$ & $\begin{array}{c}0.282 * * * \\
(0.081)\end{array}$ & $\begin{array}{c}0.01 \\
{[0.951]}\end{array}$ \\
\hline Observations & 1,105 & 1,110 & \\
\hline Science score (Medium skills) & $\begin{array}{c}0.571 * * * \\
(0.130)\end{array}$ & $\begin{array}{c}0.534 * * * \\
(0.130)\end{array}$ & $\begin{array}{c}0.07 \\
{[0.791]}\end{array}$ \\
\hline Observations & 1,105 & 1,110 & \\
\hline Science score (Higher-order skills) & $\begin{array}{c}0.416 * * * \\
(0.124)\end{array}$ & $\begin{array}{c}0.638 * * * \\
(0.139)\end{array}$ & $\begin{array}{c}2.39 \\
{[0.122]}\end{array}$ \\
\hline Observations & 1,105 & 1,110 & \\
\hline \multicolumn{4}{|c|}{ Panel C } \\
\hline Percent of correct answers & $\begin{array}{c}0.103 * * * \\
(0.023)\end{array}$ & $\begin{array}{c}0.110 * * * \\
(0.026)\end{array}$ & $\begin{array}{c}0.06 \\
{[0.800]}\end{array}$ \\
\hline Observations & 1,105 & 1,110 & \\
\hline Percent of incorrect answers & $\begin{array}{c}-0.057 * * * \\
(0.014)\end{array}$ & $\begin{array}{c}-0.050 * * * \\
(0.015)\end{array}$ & $\begin{array}{c}0.17 \\
{[0.680]}\end{array}$ \\
\hline Observations & 1,105 & 1,110 & \\
\hline Percent of omitted answers & $\begin{array}{c}-0.053 * * \\
(0.020)\end{array}$ & $\begin{array}{c}-0.079 * * * \\
(0.020)\end{array}$ & $\begin{array}{c}1.62 \\
{[0.203]}\end{array}$ \\
\hline Observations & 1,105 & 1,110 & \\
\hline
\end{tabular}

Note: ** significant at $5 \% ; * * *$ significant at $1 \%$. Robust standard errors in parentheses clustered at school level. P-values are in brackets in the third column. Controls: (i) students characteristics (gender, age, nationality, parent's education, if the student missed, at most, one class per month, if the student has internet in his home), (ii) teacher characteristics (gender, age, years of experience, if she/he has postgraduate certificates) and (iii) school characteristics (school size, $7^{\text {th }}$ size, $7^{\text {th }}$ repetition rate, FEPBA score in Language, school district -or location). All the regressions exclude the classrooms where the Human Body Unit was not taught.

Source: Authors analysis based on data described in text. 
Table 7. Results on Science learning according to teacher experience

\begin{tabular}{|c|c|c|c|}
\hline Independent variable & $(1)$ & $(2)$ & (3) \\
\hline Sequence vs. Control & $\begin{array}{c}0.574 * * * \\
(0.131)\end{array}$ & & \\
\hline Low experience & $\begin{array}{l}-0.301 \\
(0.208)\end{array}$ & $\begin{array}{l}-0.113 \\
(0.256)\end{array}$ & $\begin{array}{c}-0.752 * * * \\
(0.199)\end{array}$ \\
\hline (Sequence vs. Control)*Low experience & $\begin{array}{l}-0.333 \\
(0.282)\end{array}$ & & \\
\hline Coaches vs. Control & & $\begin{array}{c}0.570 * * * \\
(0.147)\end{array}$ & \\
\hline (Coaches vs. Control)*Low experience & & $\begin{array}{c}0.288 \\
(0.335)\end{array}$ & \\
\hline Coaches vs. Sequence & & & $\begin{array}{l}-0.175 \\
(0.141)\end{array}$ \\
\hline (Coaches vs. Sequence)*Low experience & & & $\begin{array}{c}0.824 * * \\
(0.333)\end{array}$ \\
\hline Observations & 1,042 & 1,072 & 1,102 \\
\hline \multicolumn{4}{|c|}{$\begin{array}{l}\text { Note: ** significant at 5\%; } * * * \text { significant at } 1 \% \text {. Robust standard errors in parentheses clustered at schoo } \\
\text { level. Controls: (i) students characteristics (gender, age, nationality, parent's education, if the studen } \\
\text { missed, at most, one class per month, if the student has internet in his home), (ii) teacher characteristic } \\
\text { (gender, age, general teaching experience (in years), if she/he has post-graduate certificates) and (iii) schoo } \\
\text { characteristics (school size, } 7^{\text {th }} \text { size, } 7^{\text {th }} \text { repetition rate, FEPBA score in Language, school district }-0 \\
\text { location). Low experience represents a dummy variable equals to } 1 \text { if the teacher has less than two years o } \\
\text { experience in teaching Science and zero otherwise. An interaction term between treatment status and th } \\
\text { dichotomous variable of low experience is included. All the regressions exclude the classrooms where the } \\
\text { Human Body Unit was not taught. } \\
\text { Source: Authors analysis based on data described in text. }\end{array}$} \\
\hline
\end{tabular}


Table 8. Results on Science test-scores in higher-order items according to teacher experience

\begin{tabular}{|c|c|c|c|}
\hline Independent variable & $(1)$ & (2) & (3) \\
\hline Sequence vs. Control & $\begin{array}{l}0.434 * * * \\
(0.130)\end{array}$ & & \\
\hline Low experience & $\begin{array}{l}-0.240 \\
(0.188)\end{array}$ & $\begin{array}{l}-0.034 \\
(0.223)\end{array}$ & $\begin{array}{c}-0.618 * * * \\
(0.155)\end{array}$ \\
\hline $\begin{array}{l}\text { (Sequence vs. Control)* Low } \\
\text { experience }\end{array}$ & $\begin{array}{l}-0.253 \\
(0.253)\end{array}$ & & \\
\hline Coaches vs. Control & & $\begin{array}{c}0.537 * * * \\
(0.167)\end{array}$ & \\
\hline (Coaches vs. Control)* Low experience $^{*}$ & & $\begin{array}{c}0.317 \\
(0.299)\end{array}$ & \\
\hline Coaches vs. Sequence & & & $\begin{array}{l}-0.051 \\
(0.142)\end{array}$ \\
\hline $\begin{array}{l}\text { (Coaches vs. Sequence)* Low } \\
\text { experience }\end{array}$ & & & $\begin{array}{l}0.752 * * \\
(0.301)\end{array}$ \\
\hline Observations & 1042 & 1072 & 1102 \\
\hline
\end{tabular}

Note: ** significant at 5\%; *** significant at $1 \%$. Robust standard errors in parentheses clustered at school level. Controls: (i) students characteristics (gender, age, nationality, parent's education, if the student missed, at most, one class per month, if the student has internet in his home), (ii) teacher characteristics (gender, age, general teaching experience (in years), if she/he has post-graduate certificates) and (iii) school characteristics (school size, $7^{\text {th }}$ size, $7^{\text {th }}$ repetition rate, FEPBA score in Language, school district -or location). Low experience represents a dummy variable equals to 1 if the teacher has less than two years of experience in teaching Science and zero otherwise. An interaction term between treatment status and the dichotomous variable of low experience is included. All the regressions exclude the classrooms where the Human Body Unit was not taught. Source: Authors analysis based on data described in text. 
Table 9. Effect on students' perception

\begin{tabular}{lccc}
\hline & Sequence & Coaches & \\
& vs. & vs. & Wald Test \\
& Control & Control & $(3)$ \\
& $(1)$ & $(2)$ & \\
\hline Captivate index (A+B+C+D) & $0.197 * *$ & 0.051 & 1.91 \\
& $(0.094)$ & $(0.117)$ & {$[0.166]$} \\
\hline A. This class (of Science) keeps my attention & 974 & 964 & \\
\hline B. My teacher (of Science) makes learning enjoyable & $0.100^{* *}$ & $0.118^{* *}$ & 0.13 \\
& $(0.044)$ & $(0.046)$ & {$[0.722]$} \\
\hline C. My teacher (of Science) makes lessons interesting & 0.064 & -0.049 & 2.82 \\
& $(0.063)$ & $(0.067)$ & {$[0.093]$} \\
\hline D. I like the way we learn in this class (of Science) & 0.118 & -0.012 & 3.10 \\
& $(0.073)$ & $(0.078)$ & {$[0.078]$} \\
& 1021 & 1043 & \\
\hline E. I like the class of Science & $(0.043)$ & $(0.064)$ & {$[0.260]$} \\
& 1002 & 991 & \\
\hline
\end{tabular}

Note: $* *$ significant at 5\%; *** significant at 1\%. Robust standard errors in parentheses clustered at school level. P-values are in brackets in the third column. Controls: (i) students characteristics (gender, age, nationality, parent's education, if the student missed, at most, one class per month, if the student has internet in his home and if he has a car), (ii) teacher characteristics (gender, age, years of experience, if she/he has post-graduate certificates), and (iii) school characteristics (school size, $7^{\text {th }}$ size, $7^{\text {th }}$ repetition rate, FEPBA score in Language, school district -or location). The dependent variable in A-E represents a 4-point-scale, where 1 means strongly disagree, 2 disagree, 3 agree and 4 strongly agree. The captivate index is combined scale, which construction is described in Appendix S4. All the regressions exclude the classrooms where the Human Body Unit was not taught.

Source: Authors analysis based on data described in text. 
Table 10. Teacher perceptions

\begin{tabular}{|c|c|c|c|}
\hline Dependent variable & $\begin{array}{l}\text { Sequence } \\
\text { vs. } \\
\text { Control } \\
\text { (1) }\end{array}$ & $\begin{array}{l}\text { Coaches } \\
\text { vs. } \\
\text { Control } \\
(2)\end{array}$ & $\begin{array}{l}\text { Wald test } \\
\text { (3) }\end{array}$ \\
\hline A. I feel it the way I teach Science changes a lot & $\begin{array}{c}0.864 * * * \\
(0.312)\end{array}$ & $\begin{array}{c}0.953 * * * \\
(0.247)\end{array}$ & $\begin{array}{c}0.14 \\
{[0.708]}\end{array}$ \\
\hline $\begin{array}{l}\text { B. I like and/or enjoy more teaching Science than in } \\
\text { previous years }\end{array}$ & $\begin{array}{l}0.717 * * \\
(0.345) \\
\end{array}$ & $\begin{array}{c}0.974 * * * \\
(0.307)\end{array}$ & $\begin{array}{c}0.93 \\
{[0.334]}\end{array}$ \\
\hline $\begin{array}{l}\text { C. I feel that by implementing the ideas of this } \\
\text { training, my students learned more in comparison } \\
\text { with other groups and/or subjects }\end{array}$ & $\begin{array}{r}0.632 \\
(0.333) \\
\end{array}$ & $\begin{array}{l}0.769 * * \\
(0.324) \\
\end{array}$ & $\begin{array}{r}0.30 \\
{[0.586]} \\
\end{array}$ \\
\hline $\begin{array}{l}\text { D. I feel my students develop more skills than in } \\
\text { previous years }\end{array}$ & $\begin{array}{l}0.672 * * \\
(0.293)\end{array}$ & $\begin{array}{c}0.876 * * * \\
(0.306)\end{array}$ & $\begin{array}{c}0.86 \\
{[0.354]}\end{array}$ \\
\hline E. I taught more hours of Science classes & $\begin{array}{c}0.260 \\
(0.247)\end{array}$ & $\begin{array}{l}1.107 * * * \\
(0.275)\end{array}$ & $\begin{array}{c}18.33 \\
{[0.000]}\end{array}$ \\
\hline
\end{tabular}

Note: $* *$ significant at 5\%; *** significant at $1 \%$. Robust standard errors in parentheses clustered at school level. P-values are in brackets in the third column. Controls: teacher characteristics (gender, age, years of experience, if she/he has post-graduate certificates). The dependent variables are 4-point-scale, where 1 means strongly disagree, 2 disagree, 3 agree and 4 strongly agree.

Source: Authors analysis based on data described in text. 
Table 11. Use of sequences one year later

\begin{tabular}{llc}
\hline & $\begin{array}{c}\text { Sequence } \\
(1)\end{array}$ & $\begin{array}{c}\text { Coaches } \\
\text { group } \\
(2)\end{array}$ \\
\hline $\begin{array}{l}\text { A. Teachers that continue teaching } 7^{\text {th }} \text { grade Science } \\
\text { at the same school one year after the training. }\end{array}$ & $27 \%$ & $33 \%$ \\
\hline $\begin{array}{l}\text { B. 7th grade Science Teachers in the same school } \\
\text { that continue using the sequence after the training }\end{array}$ & $100 \%$ & $89 \%$ \\
\hline Source: Authors analysis based on data described in text. & &
\end{tabular}

Source: Authors analysis based on data described in text. 